University of Nebraska - Lincoln

DigitalCommons@University of Nebraska - Lincoln

January 2003

Revision and phylogenetic analysis of the Central American endemic genus Phalangogonia Burmeister (Coleoptera:

Scarabaeidae: Rutelinae: Anoplognathini)

Andrew Smith

University of Nebraska State Museum, asmith@unl.edu

Miguel Angel Morón

Instituto de Ecologia, Veracruz, Mexico, moron_ma@ecologia.edu.mx

Follow this and additional works at: https://digitalcommons.unl.edu/entomologypapers

Part of the Entomology Commons

Smith, Andrew and Morón, Miguel Angel, "Revision and phylogenetic analysis of the Central American endemic genus Phalangogonia Burmeister (Coleoptera: Scarabaeidae: Rutelinae: Anoplognathini)" (2003). Papers in Entomology. 12.

https://digitalcommons.unl.edu/entomologypapers/12

This Article is brought to you for free and open access by the Museum, University of Nebraska State at DigitalCommons@University of Nebraska - Lincoln. It has been accepted for inclusion in Papers in Entomology by an authorized administrator of DigitalCommons@University of Nebraska - Lincoln. 


\title{
Revision and phylogenetic analysis of the Central American endemic genus Phalangogonia Burmeister (Coleoptera: Scarabaeidae: Rutelinae: Anoplognathini)
}

\author{
ANDREW B. T. SMITH \\ Division of Entomology, University of Nebraska State Museum, Lincoln, NE, U.S.A. \\ Corresponding author, Email: asmith@unlserve.unl.edu
}

MIGUEL ANGEL MORÓN

Instituto de Ecologia, Xalapa, Veracruz, Mexico

\begin{abstract}
Phalangogonia Burmeister is revised and now includes eight species: P. dispar Ohaus, P. jamesonae, sp.n., P. lacordairei Bates, $P$. obesa Burmeister, $P$. parilis Bates, $P$. punctata Franz, P. ratcliffei, sp.n. and $P$. sperata Sharp. Phalangogonia debilidens Ohaus is placed in synonymy with $P$. sperata. Lectotypes are designated for the following nominal species: $P$. dispar Ohaus, $P$. lacordairei Bates, $P$. parilis Bates and $P$. championi Bates. Neotypes are designated for: P. obesa Burmeister, $P$. sperata Sharp, $P$. stipes Sharp and $P$. debilidens Ohaus. A cladistic analysis of the species of Phalangogonia was executed using thirty-two morphological characters of adults.
\end{abstract}

\section{Introduction}

Anoplognathini is one of six tribes (Rutelini, Anomalini, Spodochlamyini, Geniatini, Adoretini and Anoplognathini) in subfamily Rutelinae (Coleoptera: Scarabaeidae). This tribe is endemic to the Australian and Neotropical Regions. Early authors (Burmeister, 1844; Lacordaire, 1856; Sharp, 1878; Ohaus, 1904a) commented on the similarities between some of the Australian and Neotropical genera. However, Ohaus (1918) classified the Australian genera into two sub-tribes and Neotropical genera into three separate subtribes, and the similarities between the Australian and Neotropical groups have not been examined since. Machatschke (1965) briefly discussed the distributional patterns of Anoplognathini but did not analyze the relationships of the sub-tribes. The five subtribes of Anoplognathini are: Anoplognathina and Schizognathina (Australia and New Guinea), and Brachysternina, Phalangogoniina and Platycoeliina (Neotropics), Carne (1956, 1957, 1958) reviewed the Australian subtribes. All of the Neotropical taxa have recently been revised: Brachysternina by Jameson E Smith (2002), Ratcliffe \& Ocampo (2002) and Smith (2002); Phalangogoniina by Smith छ. Morón (this paper); and Platycoeliina by Smith (2003). Phalangogoniina contains one genus, Phalangogonia (Fig. 1), which is endemic to Central America and southeastern Mexico. The purpose of this revision is to provide a means of identification, describe two new species, synonymize one name, make lectotype and neotype designations and to present a relationship hypothesis for the species of Phalangogonia. Ultimately, the taxonomic research on Anoplognathini will lead to a better understanding of southern hemispheric distributional patterns that are observed in many groups of organisms.

\section{Taxonomic bistory}

Burmeister (1844) first described Phalangogonia to accommodate the species $P$. obesa. Sharp (1878) later added P. sperata and $P$. stipes. Bates (1888) essentially did a review of the genus in the Biologia Centrali-Americana volume on Scarabaeoidea. Bates synonymized P. stipes under P. sperata and described P. lacordairei, P. parilis and P. championi. Ohaus (1904b) reviewed Phalangogonia as part of his monograph on the world Anoplognathini (see also Ohaus, 1904a, 1905). Ohaus synonymized P. championi under P. parilis and described P. debilidens (now a junior synonym of P. sperata), Ohaus (1904a) also erected the monogeneric family group name "Phalangogonien" based on Phalangogonia and compared the group with other Neotropical and Australian groups of anoplognathines. The family group name was later emended to Phalangogoniina by Ohaus (1918), and the group has been considered a subtribe ever since. Ohaus (1925) later added P. dispar to the genus and Franz (1955) added another species, P. punctata. Morón (1995) reviewed the Mexican species. 


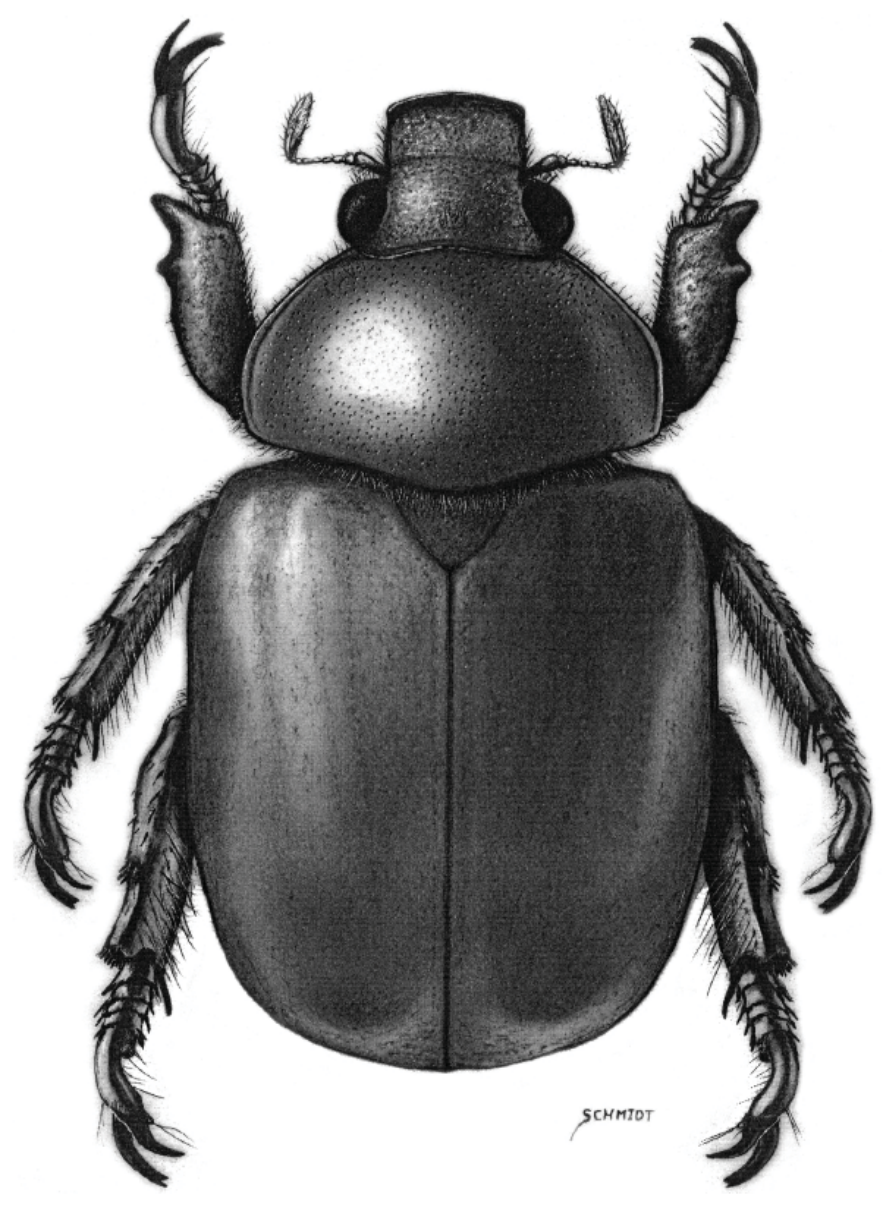

Fig. I. Habitus of male Phalangogonia ratcliffei.

\section{Geographical distribution}

Phalangogonia species are mainly found in cloud forest habitats of southern Mexico and Central America. The present distribution of the species of Phalangogonia reflects the mesoAmerican montane pattern proposed by Halffter (1978). This pattern has been observed and discussed with regards to the genera of Proculini (Scarabaeoidea: Passalidae) (Reyes-Castillo \& Halffter, 1978), genera of Heterosternina (Rutelini) (Morón, 1983) and many species of Chrysina Kirby (=Plusiotis Burmeister) (Rutelini) (Morón, 1991), Although Phalangogonia is endemic to Mexico and Central America, it is related to other groups of rutelines predominantly from South America. The early Phalangogonia species perhaps evolved in northern South America and traversed the Central American land bridge during the Pliocene. This scenario has been hypothesized for woody plant migration from South America into Central America (Burnham \& Graham, 1999). Since no Phalangogonia are known from South America, the ancestral populations either went extinct or extant populations have yet to be discovered. Another possibility is that ancestral $\mathrm{Pha}$ langogonia arrived in nuclear Central America (from Chiapas to Honduras) during the Eocene or Oligocene via Caribbean land bridges and island stepping-stones (a possibility discussed by Iturralde-Vinent \& MacPhee, 1999). A formal biogeographical analysis of Rutelinae will need to be conducted before either scenario can be substantiated using corroborating evidence.

\section{Methods and Materials}

\section{Catalogue format}

The catalogue section lists all valid (subtribal, generic, species) names in subtribe Phalangogoniina. Beneath the valid name are names used in the literature for the valid species. All names are included as they appeared in the original literature, including valid names, synonyms, lapsus calami, nomina nuda, varieties, etc., that have no nomenclatural status, and misapplied names (when the author misidentified a taxon or misused a name). Each name is followed by a list of references in which that name appeared. Each reference includes the author, date and beginning page(s) of the passage(s) mentioning the taxon as well as the nature of the content in parentheses.

\section{Specimens}

Specimens were borrowed from and deposited in thirtyfour institutions and private collections listed below (collections managers/curators listed in parentheses). Five hundred and fifty specimens formed the basis of this revision. All specimens examined were labelled with a distinctive double-bordered determination label or a yellow or red type label.

ABTS, Andrew B. T. Smith Collection, Lincoln, Nebraska, U.S.A.; BCRC, Brett C. Ratcliffe Collection, Lincoln, Nebraska, U.S.A.; BDGC, Bruce D. Gill Collection, Ottawa, Ontario, Canada; BMNH, The Natural History Museum, London, England (Malcolm Kerley); CNCI, Canadian National Collection of Insects, Ottawa, Ontario, Canada (Yves Bousquet); CSUR, Colegio de la Frontera Sur, San Cristóbal de Las Casas, Chiapas, Mexico (Jorge León Cortés); DBTC, Don B. Thomas Collection, Weslaco, Texas, U.S.A.; DCCC, David C. Carlson Collection, Fair Oaks, California, U.S.A.; DJCC, Daniel J. Curoe Collection, Palo Alto, California, U.S.A.; DEIC, Deutsches Entomologisches Institut, Eberswalde, Germany (Lothar Zerche); FMNH, Field Museum of Natural History, Chicago, Illinois, U.S.A. (Al Newton, Margaret Thayer); HAHC, Henry and Anne Howden Collection, Ottawa, Ontario, Canada; LACM, Los Angeles County Museum of Natural History, Los Angeles, California, U.S.A. (Brian Brown); INBC, Instituto Nacional de Biodiversidad (INBio), Santo Domingo de Heredia, Costa Rica (Angel Solís); JMMC, Jean-Michel Maes Collection, Leon, Nicaragua; JPBC, Jean Pierre Beraud Collection, Cuernavaca, Morelos, Mexico; MXAL, Miguel Angel Morón Collection, Xalapa, Veracruz, Mexico; MCZC, Museum of Comparative Zoology, Harvard University, Cambridge, Massachusetts, U.S.A. (Philip Per- 
kins); MGFT, Georg Frey Collection, Naturhistorisches $\mathrm{Mu}-$ seum Basel, Switzerland (Daniel Burckhardt); MLJC, Mary Liz Jameson Collection, Lincoln, Nebraska, U.SA.; NHMB, Entomologische Abteilung, Naturhistorisches Museum Basel, Switzerland (Daniel Burckhardt); OSAC, Oregon State University, Corvallis, Oregon, U.S.A. (Darlene Judd); RACC, Rich A. Cunningham Collection, Chino, California, U.S.A.; SEMC, Snow Entomological Museum, University of Kansas, Lawrence, Kansas, U.S.A. (Steve Ashe); SMFD, Forschungsinstitut und Naturmuseum Senckenberg, Frankfurt am Main, Germany (Damir Kovac); SMTD, Staatliches $\mathrm{Mu}-$ seum fur Tierkunde, Dresden, Germany (Dirk Ahrens); TAMU, Department of Entomology, Texas A \& M University, College Station, Texas, U.S.A. (Ed Riley); UCRC, Entomology Museum, University of California, Riverside, California, U.S.A. (Doug Yanega, Dave Hawks); UNSM, Division of Entomology, University of Nebraska State Museum, Lincoln, Nebraska, U.S.A. (Brett Ratcliffe); USNM, United States National Museum, Washington, D.C., U.S.A. (Dave Furth, Gloria House); UVGC, Universidad del Valle de Guatemala, Guatemala City, Guatemala (Jack Schuster); WBWC, William B. Warner Collection, Chandler, Arizona, U.S.A.; ZMHB, Museum für Naturkunde der Humboldt-Universität zu Berlin, Germany (Hella Wendt); ZSMC, Zoologische Staatssammlung, München, Germany (Max Kühbandner, Alexander Riedel).

\section{Taxonomic characters}

The following definitions and standards were used in the generic and species descriptions.

Color: based on dried, pinned specimens. We have noticed that the color of some specimens darkens considerably after death.

Body length: measured from the apex of the clypeus to the apex of the elytra.

Body width: measured at the middle of the elytra.

Puncture density: dense $=$ punctures separated by less than 2 puncture diameters to punctures overlapping; moderate $=$ punctures separated by $2-6$ puncture diameters; sparse $=$ punc tures separated by more than 6 puncture diameters.

Puncture size: large $=0.17 \mathrm{~mm}$ or more; moderately large $=0.08-0.17 \mathrm{~mm}$; moderate $=0.03-0.08 \mathrm{~mm}$; small $=0.03 \mathrm{~mm}$ or less.

Setae density: dense $=$ setae completely cover and obscure body surface; moderate $=$ setae completely cover body surface but surface clearly visible; sparse = setae do not cover body surface and surface clearly visible.

\section{Species concept}

The phylogenetic species concept outlined by Wheeler $\mathcal{E}^{\circ}$ Platnick (2000) was used in this revision.

\section{Designation of lectotypes and neotypes}

The International Code of Zoological Nomenclature (International Commission on Zoological Nomenclature, 1999) requires that designations of lectotypes after 1999 must "contain an express statement of the taxonomic purpose of the designation" (Article 74.7.3). Lectotypes were selected for the following names: $P$. dispar Ohaus, P. lacordairei Bates, $P$. parilis Bates and $P$. championi Bates. We feel that lectotypes are necessary for these names due to the long history of taxonomic confusion of species and names in this genus.

The Code requires that a designation of a neotype "is validly designated when there is an exceptional need and only when that need is stated expressly" (Article 75.3). As with the lectotype designations, four neotypes are designated in Phalangogonia to preserve the nomenclatural stability. Other qualifying conditions for designating valid neotypes in section 75.3 of the Code are satisfied in the discussions and descriptions of the individual species. Neotypes are selected for P. obesa Burmeister, P. sperata Sharp, P. stipes Sharp and P. debilidens Ohaus. We feel that these neotypes are necessary in view of the long history of taxonomic confusion of species and names in the genus. Until revisionary work is done on long neglected groups such as Phalangogonia, the taxonomy and classification are "complex zoological problems" and there is doubt surrounding the identities of all species and names.

\section{Phylogenetic methods}

Reconstruction of the phylogeny of Phalangogonia was performed using thirty-two morphological characters of adults. Smith $(2002,2003)$ discussed the methods in more detail for similar analyses. The character matrix (Table 1) used in the phylogenetic analysis was constructed using MacClade version 4.03 (Maddison \& Maddison, 2002) and analyzed using PaUP* version $4.0 \mathrm{~b} 10$ (Swofford, 2002). Anoplognathus viridiaeneus (Donovan), Platycoelia lutescens Blanchard and Platycoelia humeralis Bates were used as outgroup taxa for the analysis and to test the monophyly of Phalangogonia. The characters and character states used in the analysis are discussed below.

The data were analyzed by a branch-and-bound search using PAUP*. This method ensures that the shortest possible trees are found. The characters were unordered and of equal weight The following settings were used: initial upper bound - compute via stepwise, keep - minimal trees only, save all optimal trees, and addition sequence - furthest. The tree scores were calculated with the setting multistate taxa - polymorphism.

After an initial branch-and-bound search, the characters were re-weighted in PAUP* using the consistency index, maximum value (best fit) and base weight $=1$. After the characters were re-weighted, new branch-and-bound searches were performed. The trees were evaluated using a bootstrap method with full heuristic search and 1000 replicates. 
Table 1. Character matrix for the phylogenetic analysis of Phalangogonia.

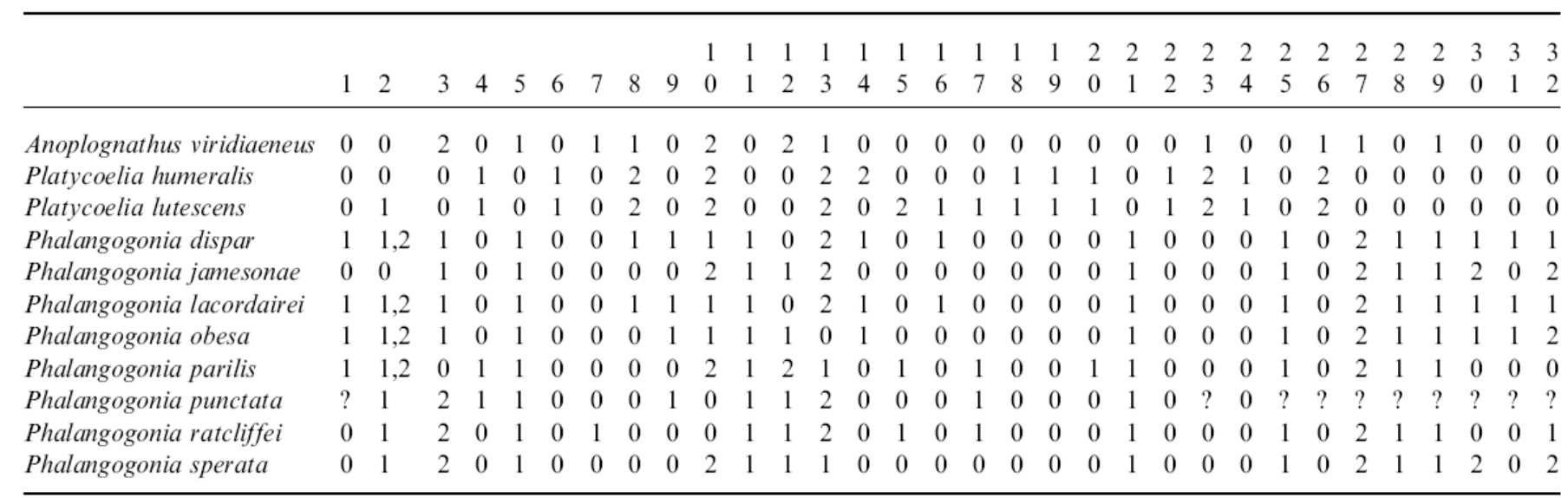

\section{Adult morphological characters used in the analysis}

1 Dorsal color dimorphism: (0) absent; (1) present.

2 Dorsal color: (0) green; (1) tan to brown; (2) black.

3 Clypeal apex: (0) subcircular; (1) broadly rounded; (2) rectangular.

4 Clypeal margin: (0) reflexed; (1) not reflexed.

5 Clypeus: (0) glabrous; (1) setose.

6 Frontoclypeal suture: (0) complete; (1) incomplete.

7 Frons: (0) glabrous; (1) setose.

8 Head: (0) densely punctate; (1) moderately punctate; (2) sparsely punctate.

9 Eyes: (0) large, rounded; (1) reduced, flattened.

10 Pronotum: (0) densely punctate; (1) moderately punctate; (2) sparsely punctate.

11 Pronotum: (0) laterally rounded; (1) angulate (with impression near angle).

12 Pygidium: (0) smooth; (1) rugose; (2) granulate.

13 Pygidial disc: (0) glabrous; (1) with short, stubblelike setae; (2) with long setae.

14 Epipleuron: (0) ventrally flat; (1) concave; (2) bladelike.

15 Mesometathoracic process: (0) extending apically to procoxa; (1) extending apically past mesocoxa; (2) reduced to a nub.

16 Mesometathoracic process: (0) parallel to body; (1) angled away from body.

17 Metasternum medially: (0) glabrous; (1) setose.

18 Tarsomere 5: (0) equal to or longer than tarsomere 1-4; (1) shorter than tarsomeres 1-4.

19 Unguitractor plate: (0) with 2 apical setae; (1) with 1 apical and 1 subapical seta.

20 Protibia: (0) greatly widened; (1) regular.

21 Protibia:(0) with spur; (1) without spur.

22 Mesotibia: (0) thickened; (1) frail, gracile.

23 Modified mesoclaw of male: (0) thickened, split; (1) simple; (2) split apicoventrally.

24 Metatibia: (0) thickened; (1) frail, gracile.

25 Metatarsomere 5 of male: (0) with median tooth; (1) with basal tooth.
26 Modified metaclaw of male: (0) thickened, split; (1) simple; (2) split apicoventrally.

27 Phallobase: (0) longer than parameres; (1) shorter than parameres; (2); greatly reduced.

28 Phallobase and parameres: (0) distinct; (1) completely fused.

29 Parameres: (0) not fused; (1) fused basally and medially.

30 Parameres: (0) apicodorsally flat; (1) with medial ridge; (2) with 2 ridges.

31 Parameres mediodorsally: (0) flat; (1) convex with ridge.

32 Parameres: (0) apically rounded; (1) quadrate; (2) constricted.

\section{Key to the species of Phalangogonia}

1. Pygidial disc appearing smooth, without noticeable microsculpturing (some scattered punctures and setae present); mesometasternal process robust, declivous (sloping away) with respect to venter ................ 2

- $\quad$ Pygidial disc shagreened, rugose or granular; mesometasternal process weak to robust, apex parallel with respect to venter . . . . . . . . . . . . . . . . . 3

2(1). Metatarsomeres 1-3 with well developed pad of ventral spines and setae; male parameres with distinct dorsomedial keel, apices with strong tooth (Fig. 2E,F); Puebla, Veracruz, Oaxaca and Veracruz, Mexico . . . lacordairei Metatarsomeres 1-3 with weak pad of ventral spines and setae; male parameres with poorly defined dorsomedial keel, apices with weak tooth (Fig. 2A,B); eastern Guatemala to northwestern Honduras ........... dispar

3(1). Eyes small, almost flush with side of head in dorsal view (Fig. 3A)........................ Eyes bulbous, distinctly protruding from side of head in dorsal view (Figs 1,3B,C) . ............

4(3). Pronotum with sparse, scattered punctures; clypeus with surface mainly glabrous (sometimes with sparse, scattered setae); southern Mexico to Guatemala ... . obesa Pronotum with dense, sometimes confluent punctures; clypeus with surface uniformally setose; El Salvador .......................... 

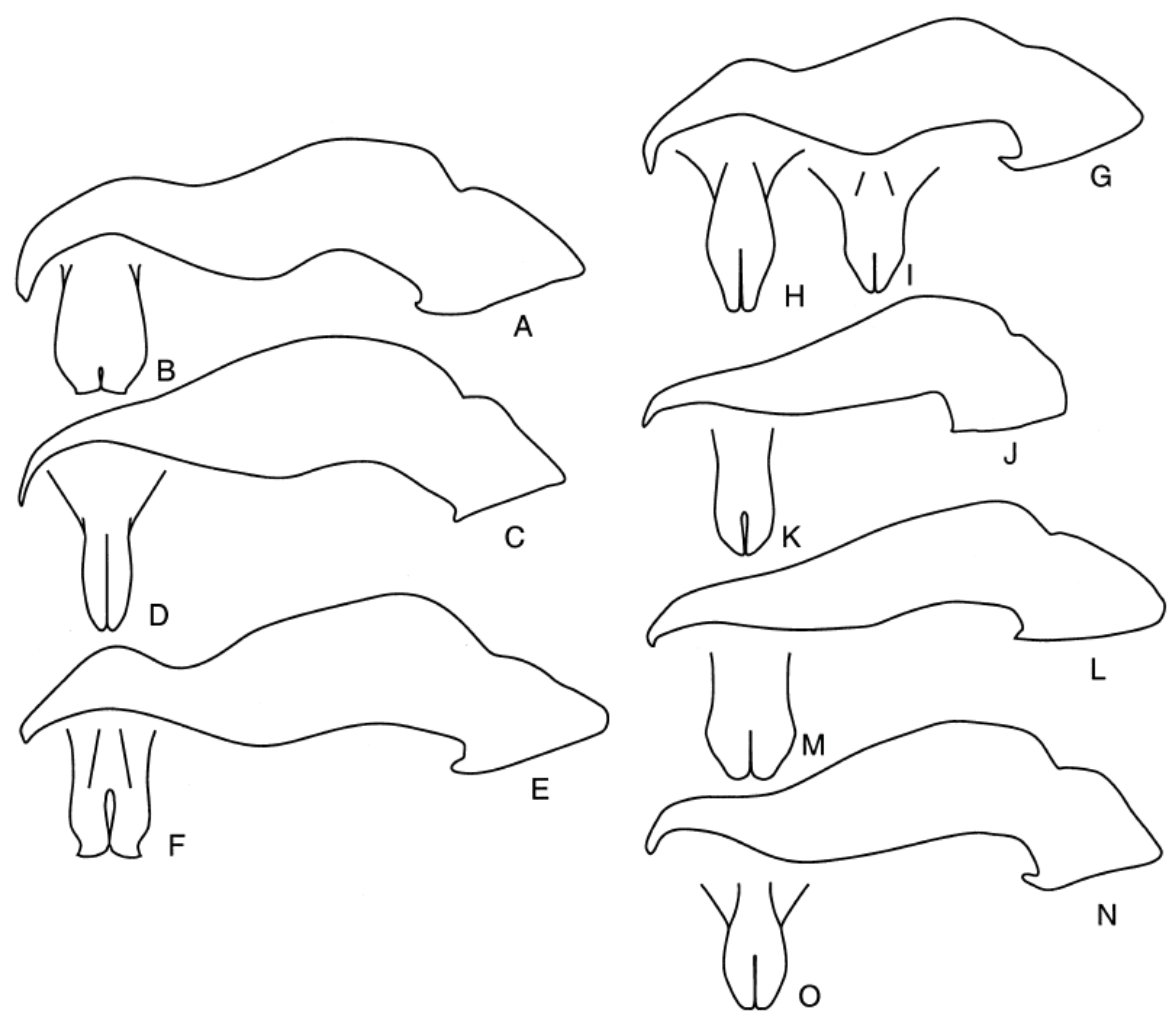

Fig. 2. Male genitalia of Phalangogonia. A, P. dispar phallobase and paramere; B, P. dispar apex of parameres; C, P. jamesonae phallobase and paramere; D, P. jamesonae apex of parameres; E, P. lacordairei phallobase and paramere; F, P. lacordairei apex of parameres; G, P. obesa phallobase and paramere; $\mathbf{H}, \mathbf{I}$, P. obesa apex of parameres (two forms); J, P. parilis phallobase and paramere; K, P. parilis apex of parameres; L, P. ratcliffei phallobase and paramere; $\mathbf{M}$, P. ratcliffei apex of parameres; $\mathbf{N}$, P. sperata phallobase and paramere; O, P. sperata apex of parameres.

5(3). Mesometasternal process produced to or surpassing base of procoxae. .........................6

- Mesometasternal process not reaching base of procox-

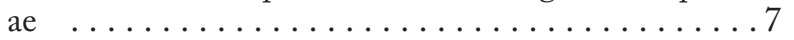

6(5). Dorsal color mostly pale green; male parameres as in Fig. 2C, D; Oaxaca, Mexico .............. jamesonae Dorsal color tan or light to dark yellowish-brown (sometimes creamy white when alive); male parameres as in Fig. 2N,O; Nicaragua to Panama........... sperata

7(5). Head dorsally glabrous; pygidium brown to black, granulate; length 18-24 mm; Quezaltenango, Guatemala.... .................................. Head dorsally setose; pygidium tan, not granulate but with obvious microsculpturing; length 24-31 mm; Oaxaca to Chiapas, Mexico ............... ratcliffei

\section{Subtribe Phalangogoniina Ohaus, 1904}

Phalangogonien (emended to Phalangogoniina): Ohaus, 1904a: 64 (comparison with other "Anoplognathiden"); Ohaus, 1904b: 257, 277 (comparison with other "Anoplognathiden"); Ohaus, 1905:124 (comparison with Brachys- ternidae).

Phalangogoniina: Ohaus, 1918: 176 (catalogue listing); Blackwelder, 1944: 246 (checklist); Machatschke, 1965: 10, 13, 53 (distribution, catalogue listing); Machatschke, 1972:299 (catalogue listing); Morón, 1997:49 (redescription); Delgado et al., 2000: 31 (key to genera of Mexican Scarabaeoidea); Smith, 2002: 380, 389 (distribution, key to Neotropical genera of Anoplognathini).

Palangogoniina (= Phalangogoniina, lapsus calami): Morón, 1995:195 (review of Mexican species).

Type genus. Phalangogonia Burmeister.

\section{Genus Phalangogonia Burmeister, 1844}

Phalangogonia: Burmeister, 1844: 433, 436, 451 (key to genera of Anoplognathidae, original description); Lacordaire, 1856: 368, 370 (key to genera of "Anoplognathides", redescription); Harold, 1869: 1229 (catalogue listing); Sharp, 1878: 129 (comment on similarities with Australian "Anoplognathi"); Bates, 1888: 291 (distribution); Ohaus, 1904a: 64 (comparison with other genera of 

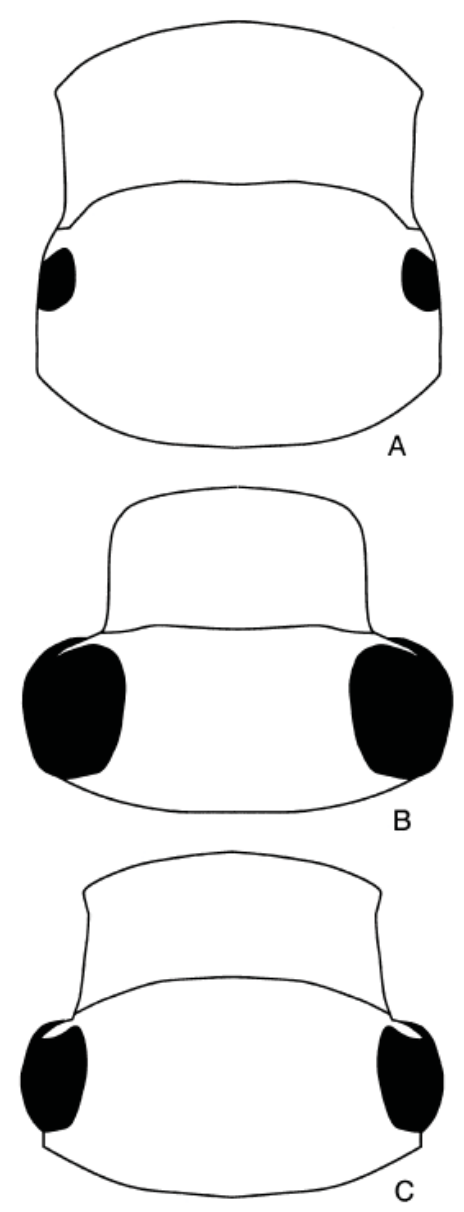

Fig. 3, Head of male Phalangogonia species. A, P. lacordairei B, P. ratcliffei; C, P. sperata.

“Anoplognathiden"); Ohaus, 1904b: 261, 275, 338 (key to American "Anoplognathiden", redescription, species list); Ohaus, 1905: 145 (comparison with Brachysternus); Ohaus, 1918: 176 (catalogue listing); Blackwelder, 1944: 246 (checklist); Machatschke, 1965: 3, 7, 13, 53 (distribution, catalogue listing, redescription); Machatschke, 1972: 300 (catalogue listing); Morón, 1994: 18 (checklist); Morón, 1995: 195, 200 (review of Mexican species, comment on distribution); Morón, 1997: 49 (redescription); Delgado et al. 2000: 31 (key to genera of Mexican Scarabaeoidea); Ratcliffe, 2002: 26 (checklist); Smith, 2002: 389 (key to Neotropical genera of Anoplognathini).

Phalogogonia (= Phalangogonia, lapsus calami): Browne $छ$ Scholtz, 1995: 173 (phylogeny of Scarabaeoidea); Browne E' Scholtz, 1998: 323 (phylogeny of Scarabaeoidea).

Type species. Phalangogonia obesa Burmeister, fixed by monotypy.

Diagnosis. This genus is distinguished from an other genera of Anoplognathini by the following combination of characters: elytron without membranous border, glabrous; mesometaster- nal process well developed; protibia without spur; tarsomere 5 with tooth; claws split or toothed (not simple); unguitractor plate with 2 setae; male genitalia with phallobase and parameres fused, parameres with apices close together (not widely separated); last abdominal sternite in females with apex entire (not emarginate).

Description. Length 18.1-32.6 mm, width $10.0-17.6 \mathrm{~mm}$. Color dorsally various shades of tan, reddish-tan, brownishtan, green or black. Head: Clypeus densely punctate, punctures moderate in size to moderately large, glabrous or setose. Clypeal apex rounded to rectangular, weakly to strongly reflexed. Frontoclypeal suture complete or obscured medially. Frons sparsely to densely punctate, glabrous (setose in P. ratcliffei). Labrum with apex vertically produced with respect to clypeus, produced at middle, triangular. Mandibles with proximal molar lobe well developed with more than 10 black lamellae. Mentum setose, apex strongly reflexed into oral cavity. Antenna 10-segmented with 3-segmented club. Pronotum: Form widest at middle, basomedially protuberant towards posterior. Surface sparsely to densely punctate with moderately large punctures, glabrous (medioapically setose in $P$. ratcliffei). Marginal bead present laterally, Scutellum: Surface glabrous (sometimes setose in P. ratcliffei). Elytron: Surface glabrous, longitudinal striae weakly defined. Epipleuron rounded, marginal bead complete. Hind wing: Leading margin without row of setae on apical half. Pygidium: Surface evenly convex, sparsely punctate to rugose or granular, setose; setae long, slender, tawny to cream-colored. Apex evenly rounded. Venter: Thorax densely to moderately setose (moderately setose to glabrous medially); setae usually long, tawny. Prothoracic and metathoracic processes absent. Abdominal sternites sparsely setose. Apical abdominal sternite of female not deeply emarginate. Legs: Coxae, trochanters and femora sparsely to moderately setose. Protibia with 3 teeth in apical half. Male tarsal claws with modified claw thickened and bifurcate. Female tarsal claws with ventral tooth on modified claw. Protarsomere 4 without recurved spines. Tarsomere 5 with ventrobasal tooth (sometimes vestigial). Unguitractor plate cylindrical, produced beyond apex of tarsomere 5, with 2 apical setae. Male Genitalia (Fig. 2A-O): Form symmetrical in caudal view. Phallobase fused to parameres. Parameres fused together except at apex,

Distribution (Fig. 4). East central Mexico to Panama.

Phalangogonia dispar Ohaus, 1925 (Figs 2A, B, 4)

Phalangogonia dispar: Ohaus, 1925: 81 (original description); Blackwelder, 1944: 246 (checklist); Machatschke, 1965: 54 (catalogue listing); Machatschke, 1972: 300 (catalogue listing).

Type specimens. Phalangogonia dispar Ohaus, 1925. Lectotype hereby designated: male at MGFT, labelled "S. Pedro Sula Honduras" (typeface), // "Ohaus determ. Phalangogonia dispar Ohs. 0 Cotype" (typeface and handwritten), // "Phalangogonia dispar" (handwritten) // "PHALANGOGONIA DISPAR OHAUS $\widehat{\partial}$ LECTOTYPE A. B. T. SMITH 2001” (red type label, handwritten and typeface). Type locality: San 


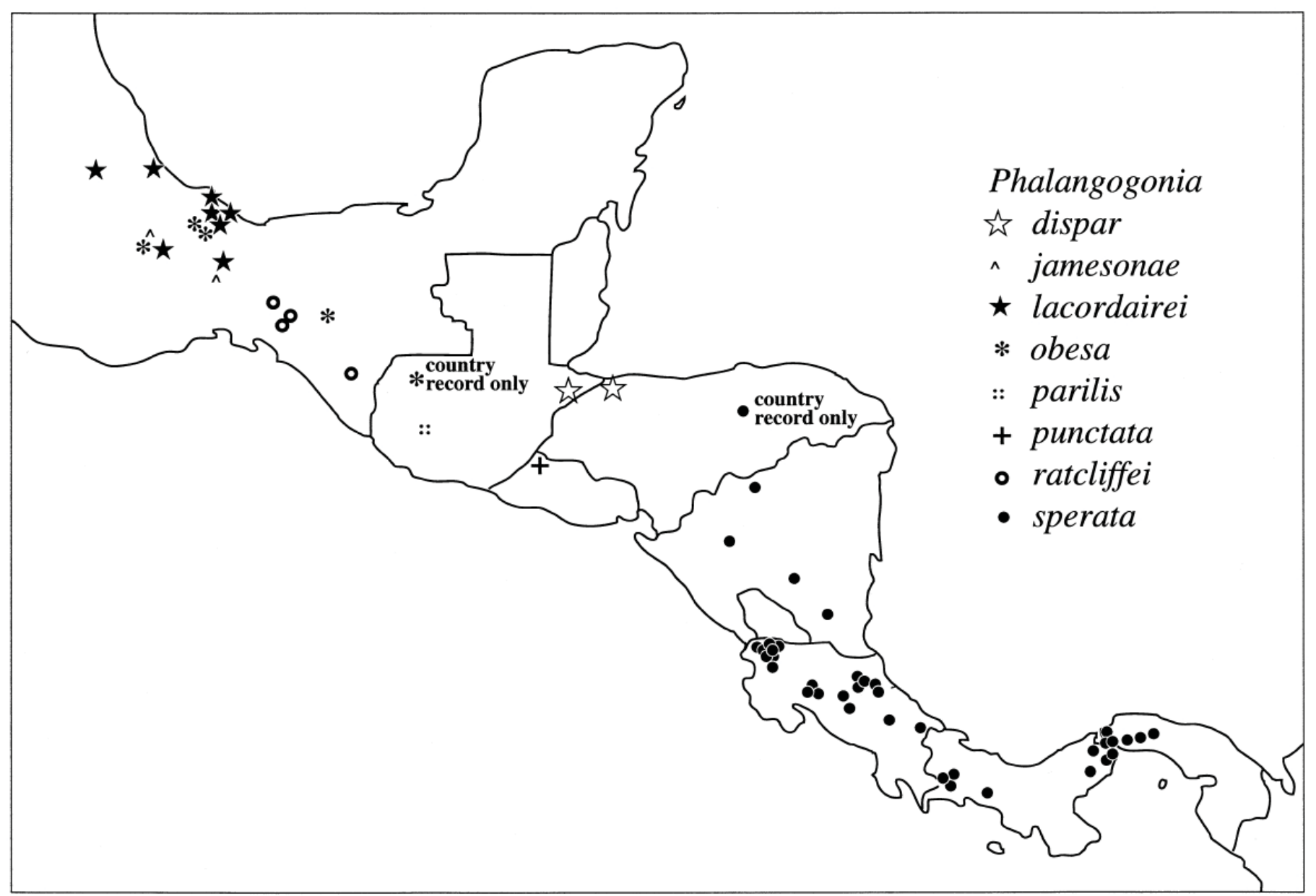

Fig. 4. Distribution of Phalangogonia species in Central America.

Pedro Sula, Honduras. One female paralectotype at MGPT labelled "S. Pedro Sula Honduras" (typeface), // "Ohaus determ. Phalangogonia dispar Ohs. O Cotype" (typeface and handwritten), // "27" (typeface), // "Phalangogonia dispar" (handwritten) // "PHALANGOGONIA DISPAR OHAUS q DET: A. B. T. SMITH 2001 PARALECTOTYPE” (yellow type label, handwritten and typeface). One female paralectotype at ZMHB labelled "S. Pedro Sula Honduras" (typeface), // "O”" (typeface), // Cotypus!" (red label, typeface), // "Zool. Mus. Berlin" (typeface) // "PHALANGOGONIA DISPAR OHAUS $\&$ DET: A. B. T. SMITH 2001 PARALECTOTYPE" (yellow type label, handwritten and typeface). Ohaus (1925) stated that there were two male and two female specimens in the type series. One male paralectotype was lost in the mail between ZMHB and MXAL in 1993.

Diagnosis, This species is distinguished from all other species in Phalangogonia by the following combination of characters: dorsal color blade or dark: reddish-tan; frons glabrous; eye small, flush with side of head in dorsal view; pronotum sparsely punctate; pygidial disc appearing smooth; mesometasternal process robust, declivous with respect to venter; male genitalia as in Fig. 2A,B. With the short series exam- ined, it is unclear if this species has black males and dark reddish-tan females or if each of the two color variations can be found in both sexes.

Description. Male $(\mathrm{n}=2)$ : Length $21.5-25.1 \mathrm{~mm}$, width 12.0-13.3 mm. Color black. Head: Clypeus rectangular, reflexed strongly at apex, densely punctate, with moderately large to moderate-sized punctures, apex with sparse setae. Frontoclypeal suture complete, weakly bisinuate. Frons sparsely punctate, with moderately large to moderate-sized punctures, glabrous. Eye small, flush with side of head in dorsal view, length in lateral view $0.21 \times$ head length in lateral view. Pronotum: Surface sparsely punctate, with moderate-sized punctures, glabrous. Elytron: Surface glabrous. Striae weakly defined. Pygidium: Width $2.0 \times$ length medially. Surface without noticeable microsculpturing, moderately setose with long, yellowish-brown setae. Venter: Thorax glabrous medially, moderately setose laterally; setae long, yellowish-brown. Mesometasternal process declivous with respect to venter, apex adjacent to procoxae. Abdominal sternites sparsely setose. Legs: Metatarsomeres 1-3 with ventral pad of thick, black setae. Protarsomere 5 with vestigial ventrobasal tooth. Mesotarsomere 5 and metatarsomere 5 with prominent ventrobasal tooth. Tarsal 
claws with modified claw thickened when compared to other claw, apex bifurcate. Male genitalia (Fig. 2A,B): Dorsomedial keel poorly defined, apex with weak tooth. Female $(\mathrm{n}=2)$ : Length 23.1-23.7 mm, width 12.1-12.9 mm. As male except in following respects. Color dorsally dark reddish-tan. Head: Clypeal apex rounded, not reflexed. Legs: Tarsal claws with modified claw with ventral tooth, not thickened when compared to other claw, apex not bifurcate.

Distribution (Fig. 4). Eastern Guatemala (Sierra de las Minas) to adjacent mountain ranges in northwestern Honduras (Sierra de Omoa). The following localities are based on four specimens examined from MGFT, UVGC, and ZMHB. GUATEMALA: Izabal: Los Amates. HONDURAS: Cortéz: San Pedro Sula.

Seasonal data. August.

\section{Phalangogonia jamesonae, sp.n. (Fig. 2C,D, 4)}

Phalangogonia obesa forma prasina (infrasubspecific name, unavailable): Morón, 1995: 196 (description).

Phalangogonia obesa (partially misapplied): Morón, 1997: 50, 124 (redescription).

Type specimens. Male holotype deposited at MXAL, one male paratype deposited at UNSM. Holotype labelled "MEXICO: Qaxaca Chiltepec 7-IX-801. González, col. COLECCION M. A. Morón, MEXICO” (handwriting and typeface, black border), // "Phalangogonia obesa Burm. M. A. Morón, det. 95" (handwriting and typeface, black border). Type locality: Chiltepec, Oaxaca, Mexico. Paratype labelled "MEXICO, OAXACA 12 KM W PALOMARES AUG. 11-12 1980 E. GIESBERT" (handwriting and typeface), // "University Calif. Riverside Ent. Res. Museum UCRC ENT 00033821” (typeface). Paratype is damaged with missing antennae and tarsal segments. This species was referred to as the "forma prasina" of $P$. obesa by Morón (1995). Since the name "prasina" referred to an intrasubspecific entity it has no nomenclatural status and is not an available name. In Morón (1997: Fig. 28e), a photograph of the holotype of $P$. jamesonae is shown (under the name $P$. obesa). A detailed study of more specimens of $P$. obesa revealed many consistent differences between that species and $P$. jamesonae. The most obvious external character is the form of the eyes (bulbous in P. jamesonae and flattened in P. obesa). There are also notable differences in the form of the male genitalia (see Fig. 2C,D,G,I). Morón (1995) listed another male specimen with the label data "MEXICO: Qaxaca, Istmo, agost. 74, A. Diaz F. leg." This specimen was not available for this revision and is not part of the type series (it is housed at JPBC).

Diagnosis. This species is distinguished from all other species in Phalangogonia by the following combination of characters: dorsal color light olive green to light green; frons glabrous; eye bulbous, protruding from side of head in dorsal view; pronotum sparsely to moderately punctate; pygidial disc shagreened to granular; mesometasternal process robust, not declivous with respect to venter; male genitalia as in Fig. 2C,D.

Holotype. Male. Length $26.4 \mathrm{~mm}$, width $14.0 \mathrm{~mm}$. Color light olive green; abdominal sternites brown. Head: Dorsal surface densely punctate. Clypeus setose, rectangular, apex reflexed. Clypeal apex ventrally thickened beyond oral cavity. Frontoclypeal suture complete, straight. Eye large, bulbous, length in lateral view $0.33 \times$ head length in lateral view. Antenna 10-segmented, club length subequal to length of segments 2-6. Labrum broadly triangular, produced perpendicular to clypeus. Mentum at apex with strong medial tooth reflexed into oral cavity. Pronotum: Surface glabrous, sparsely to moderately punctate. Lateral border distinct; apical, basal borders indistinct. Elytron: Surface glabrous. Striae weakly defined, punctate, with moderate-sized punctures. Pygidium: Width $2.3 \times$ length medially. Surface glabrous except scattered setae near apex. Venter: Thorax glabrous medially, moderately setose laterally; setae long, yellowish-brown. Mesometasternal process projecting parallel to body, apex adjacent to procoxae. Abdominal sternites sparsely setose. Legs: Protibia with 3 teeth. Mesotibia, metatibia with weakly developed medial carina. Tarsomeres 1-4 wider than long, cup-shaped. Mesotarsomere and metatarsomere 1-3 with ventral pad of thick, yellowish-brown setae. Tarsomere 5 elongate, with weak ventrobasal tooth. Tarsal claws with modified claw thickened when compared to other claw, apex bifurcate. Male genitalia (Fig. $2 \mathrm{C}, \mathrm{D})$ : Dorsomedially without keel or swelling; apex constricted, without tooth.

Variation (1 male paratype). Length $27.3 \mathrm{~mm}$, width 15.0 $\mathrm{mm}$. Color light green. The paratype does not differ significantly from the holotype. Female unknown.

Etymology. The species group name is a noun in the genitive case for "Jameson's Phalangogonia." It is our pleasure to name this species after Mary Liz Jameson, an expert on Rutelinae taxonomy. One of us (ABTS) is particularly grateful for her mentoring, generous nature, and wholehearted encouragement during the course of his training as a scarab beetle taxonomist.

Distribution (Fig. 4). Known only from north-eastern Oaxaca, Mexico. The following localities are based on 2 specimens examined from MXAL and UNSM. MEXICO: Oaxaca: Chiltepec, Palomares (12km W).

Seasonal data. August and September.

\section{Phalangogonia lacordairei Bates, 1888 (Figs 2E,F, 3A, 4)}

Phalangogonia obesa (misapplied): Lacordaire, 1856: 371 (comment on morphology).

Phalangogonia lacordairei: Bates, 1888: 292 (original description) Ohaus, 1904b: 265, 267, 338, 340 (redescription); Ohaus, 1918: 176 (catalogue listing); Ohaus, 1925: 81 (comparison with $P$. dispar), Blackwelder, 1944: 246 
(checklist); Machatschke, 1965: 55 (catalogue listing); Machatschke, 1972: 300 (catalogue listing); Morón, 1995: 95, 198 (redescription, comment on biology); Morón E̋ Blackaller, 1997: 229, 241 (biology, checklist); Morón, 1997: 50, 124 (redescription).

Type specimens. Phalangogonia lacordairei Bates (1888). Lectotype hereby designated: male at BMNH, labelled "Type" (round label, red border, typeface), // "Sp. figured." (typeface), // "Cordova" (typeface) // "Mexico. Salle Coll." (typeface), // "1194" (green label, typeface), // "Phalangogonia lacordairei = obesa, Lac. dond (?) Salle”" (handwritten), // "B.C.A. Col., II. (2), Phalangogonia lacordairei, Bates" (typeface and handwritten), // "PHALANGOGONIA LACORDAIREI BATES 9 LECTOTYPE A. B. T. SMITH 2001” (red type label, handwritten and typeface). Type locality: Córdoba, Veracruz, Mexico. Bates (1888) stated that there were two female specimens in the type series. The location of the female paralectotype is unknown. One specimen labelled "Typus" was lost in the mail between ZMHB and MXAL in 1993. It is uncertain if this was the missing female paralectotype.

Diagnosis. This species is distinguished from all other species in Phalangogonia by the following combination of characters: dorsal color black or tan to reddish-tan; frons glabrous; eye flush with side of head in dorsal view; pronotum sparsely punctate; pygidial disc appearing smooth; mesometasternal process robust, declivous with respect to venter; male genitalia as in Fig. 2E,F.

Description. Male ( $\mathrm{n}=23$ ): Length 23.1-28.2 mm, width 12.0-15.9 mm. Color black or dorsally tan to reddish-tan, ventrally reddish-tan to reddish-brown. Head: Clypeus rectangular, reflexed strongly at apex, densely punctate, with moderately large to moderate-sized punctures. Frontoclypeal suture complete. Frons moderately punctate, with moderately large to moderate-sized punctures. Eye small, flush with side of head in dorsal view, length in lateral view $0.19 \times$ head length in lateral view, Pronotum: Surface sparsely punctate, with moderate-sized punctures, glabrous. Elytron: Surface glabrous. Striae weakly defined. Pygidium: Width $2.1 \times$ length medially. Surface moderately setose in apical half with long, yellowishbrown setae. Venter: Thorax glabrous medially; moderately setose laterally; setae long, yellowish-brown. Mesometasternal process slightly angled away from body, apex adjacent to procoxae. Abdominal sternites sparsely setose. Legs: Metatarsomeres 1-3 with weak ventral pad of setae. Protarsomere 5 with vestigial ventrobasal tooth. Mesotarsomere 5 and metatarsomere 5 with prominent ventrobasal tooth. Tarsal claws with modified claw thickened when compared to otter claw, apex bifurcate. Male genitalia (Fig. 2E,F): Dorsomedial keel well defined, apex with distinct tooth. Female $(\mathrm{n}=17)$ : Length 25.3$29.4 \mathrm{~mm}$, width $13.2-17.6 \mathrm{~mm}$. As male except in following respects. Head: Clypeal apex rounded, not reflexed. Legs: Tarsal claws with modified claw with ventral tooth, not thickened when compared to other claw, apex not bifurcate.
Habitat. Morón \& Blackaller (1997) reported that this species was found on Quercus (Fagaceae) foliage in San Martin, Veracruz (800-1050 m in elevation). Dr. Julieta Ramos reports that the Nahua indigenous people in the Sierra Norte de Puebla, Mexico (Santiago Yancuitlalpan) use the larvae and adults of P. lacordairei as a seasonal food. Live specimens were collected in August under rich organic soil in the forest and placed on a hot plate. They were eaten with corn tortilla and hot chili sauce.

Distribution (Fig, 4), Recorded from 500 to $3100 \mathrm{~m}$ in elevation in central and southern Veracruz, Mexico, and adjacent areas. The following localities are based on forty-eight specimens (seven without data) examined from BCRC, BDGC, BMNH, CNCI, HAHC, MLJC, MXAL, RACC, UCRC, UNSM, UVGC, and WBWC. MEXICO: Oaxaca: Puerto Eligio; Puebla: Santiago Yancuitlalpan; Veracruz: Catemaco, Córdoba, Jesús Carranza, San Pedro de Soteapan, Sontecomapan (15 km W), Volcán San Martín.

A series of four specimens were collected in "Santa Rosa." The labels listed either Chiapas or Veracruz as the state but appeared to be from the same collecting event. Since there are several places called Santa Rosa in both Chiapas and Veracruz, these specimens are considered to be from Mexico with no further data.

Seasonal data. June through September.

\section{Phalangogonia obesa Burmeister, 1844 (Figs 2G-I, 4)}

Phalangogonia obesa: Burmeister, 1844: 452 (original description); Harold, 1869: 1229 (catalogue listing); Sharp, 1878: 129 (comment on morphology); Bates, 1888: 291 (redescription); Ohaus, 1904b: 266, 268, 271, 338, 340 (redescription); Ohaus, 1918: 176 (catalogue listing); Blackwelder, 1944: 246 (checklist); Machatschke, 1965: 55 (erroneous catalogue listing as synonym of P. lacordairei, Machatschke, 1972: 300 (catalogue listing); Morón, 1995: 195, 196 (redescription); Morón, 1997: 50, 124 (redescription).

Phalangogonia parilis (misapplied): Thomas, 1993: 402 (checklist).

Type specimens. Phalangogonia obesa Burmeister, 1844. Neotype hereby designated: male at BMNH, labelled "Chinantla" (typeface), // "Mexico. Salle Coll." (typeface), // "1192" (green label, typeface), // "Phalangogonia obesa ${ }^{\lambda}$ " (handwritten), // "B.C.A. Col.II. (2)" (typeface), // "PHALANGOGONIA OBESA BURMEISTER $\widehat{\sigma}$ NEOTYPE A. B. T. SMITH 2001" (red label, handwritten and typeface). Type locality: Chinantla, Oaxaca, Mexico. Burmeister (1844) indicated that the description for this species is based on one male specimen from the "Dupont collection." Other authors have commented that the holotype was actually a female (Sharp, 1878; Bates, 1888). Horn et al. (1990) list the Dupont collection as now being housed mainly at BMNH ("Lamellicorn") or Museum National 
d'Histoire Naturelle (MNHN) in Paris (with other Coleoptera). These collections were searched during a recent trip (by ABTS) without success (it appears that all specimens of Phalangogonia from MNHN have disappeared). Inquiries were also made at the Martin-Luther-Universität, Wissenschaftsbereich Zoologie, Halle, Germany, where most of Burmeister's types are housed. According to Karia Schneider (curator of Coleoptera) there are no specimens of Phalangogonia in their collection. We can only conclude that the holotype has been lost. The original type was from "Mexico." We selected the neotype from Chinantla, Mexico (a region on the Gulf slopes of the northern Oaxaca Mountains near the border of Veracruz) with precise locality data and remained true to the original type locality. The neotype is in agreement with the original description for the species by Burmeister (1844).

Diagnosis. This species is distinguished from all other species in Phalangogonia by the following combination of characters: dorsal color tan, dark reddish-brown, or black; frons glabrous; eye flush with side of head in dorsal view; pronotum sparsely punctate; pygidial disc shagreened to rugose; mesometasternal process robust, weakly to not declivous with respect to venter; male genitalia as in Fig. 2G-I.

Description. Male ( $\mathrm{n}=7$ ): Length 18.1-24.4 mm, width 10.0-14.3 mm. Color dorsally tan, dark reddish-brown, or black. Head: Clypeus rectangular, reflexed strongly at apex, densely punctate with moderately large to moderate-sized punctures, sometimes with sparse setae at apex. Frontoclypeal suture complete, weakly bisinuate. Frons densely punctate, with moderately large to moderate-sized punctures, glabrous. Eye small, flush with side of head in dorsal view, length in lateral view $0.21 \times$ head length in lateral view. Pronotum: Surface sparsely punctate with moderatesized punctures, glabrous. Elytron: Surface glabrous. Striae weakly defined. Pygidium: Width $2.0 \times$ length medially. Surface densely punctate to weakly rugose, glabrous. Venter: Thorax glabrous medially, moderately setose laterally; setae long, yellowish-brown. Mesometasternal process slightly angled away from body, apex adjacent to procoxae. Abdominal sternites sparsely setose. Legs: Metatarsomeres 1-3 with ventral pad of thick, yellowish-brown setae. Protarsomere 5 with small ventrobasal tooth. Mesotarsomere 5 and metatarsomere 5 with prominent ventrobasal tooth. Tarsal claws with modified claw thickened when compared to other claw, apex bifurcate. Male genitalia (Fig. 2G-I): Dorsomedial keel distinct, apex diamond-shaped (Fig. 2H) to parallel sided (Fig. 2I), without distinct tooth. Female $(\mathrm{n}=5)$ : Length $21.8-25.7 \mathrm{~mm}$, width $11.6-13.1 \mathrm{~mm}$. As male except in following respects. Color dorsally tan. Head: Clypeal apex rounded, not reflexed. Legs: Tarsal claws with modified claw with ventral tooth, not thickened when compared to other claw, apex not bifurcate.

Habitat. Thomas (1993) reported (under the name P.parilis) that $P$. obesa occurs in montane rain forest habitat in Chiapas.
Distribution (Fig. 4). Recorded at $600-970 \mathrm{~m}$ in elevation from Veracruz, Mexico, to Guatemala. The following localities are based on twelve specimens (two specimens with no data) examined from BCRC, BMNH, CNCI, MXAL, NHMB, SMFD, SMTD, USNM, WBWC, and ZMHB. MEXICO: Chiapas: Parque Laguna Belgica; Oaxaca: Chinantla, Puerto Eligio. Valle Nacional; Veracruz: El Bastonal; no data. GUATEMALA: No data.

Seasonal data. July and September.

\section{Phalangogonia parilis Bates, 1888 (Figs 2J,K, 4)}

Phalangogonia parilis: Bates, 1888: 293 (original description); Ohaus, 1904b: 262, 270, 338, 340 (redescription); Ohaus, 1918: 176 (catalogue listing); Machatschke, 1965: 55 (catalogue listing); De Ruette, 1970: 92 (catalogue listing); Machatschke, 1972: 300 (catalogue listing).

Phalangogonia champions: Bates, 1888: 293 (original description); Ohaus, 1904b: 262, 271 (placed in synonymy with $P$. parilis); Ohaus, 1918: 176 (catalogue listing as synonym of P. parilis); Blackwelder, 1944: 246 (checklist as synonym of P. parilis); Machatschke, 1965: 55 (catalogue listing as synonym of P. parilis); Machatschke, 1972: 300 (catalogue listing as synonym of $P$. parilis).

Phalangogonia parillis (= P. parilis, lapsus calami: Blackwelder, 1944: 246 (checklist).

Type specimens. Phalangogonia parilis Bates, 1888. Lecto-type hereby designated: male at BMNH, labelled "Type" (round label, red border, typeface), // "Phalangogonia parilis Bates" (handwritten), // "Sp. figured." (typeface), // "Cerro Zunil, 4-5000 ft. Champion." (typeface), // "B.C.A., Coll., II. (2). Phalangogonia" (typeface), // "PHALANGOGONIA PARILIS BATES $\widehat{\delta}$ LECTOTYPE A. B. T. SMITH 2001” (red type label, handwritten and typeface). Type locality: Cerro Zunil, Guatemala. Four male paralectotypes at BMNH labelled (with slight variations) " $>$ " (typeface), // "Cerro Zunil, 4-5000 ft. Champion." (typeface), // "Phalangogonia parilis Bates" (handwritten), // "B.C.A., Coll., II. (2). Phalangogonia parilis" (typeface and handwritten), // "PHALANGOGONIA PARILIS BATES $\lesssim$ DET A. B. T. SMITH 2001 PARALECTOTYPE” (yellow type label, handwritten and typeface). One male paralectotype at CNCI labelled' “ ' (typeface), // "Phalangogonia parilis Bates" (handwritten), // "B.C.A., Coll., II. (2)" (typeface), // "COTYPE 8126 CNCNo. Phalangogonia parilis Bates" (yellow type label, typeface and handwritten), // "PHALANGOGONIA PARILIS BATES $\precsim$ DET: A. B. T. SMITH 2001 PARALECTOTYPE” (yellow type label, handwritten and typeface). One male paralectotype at HAHC labelled "Cerro Zunil, 4-5000 ft. Champion." (typeface), // "H. \& A. HOWDEN COLLECTION ex. A. Martinez coll." (typeface), // “ '” (typeface), // "COTYPUS" (faded red label, typeface), // "B.C.A., Coll., II. (2). Phalangogonia parilis, Bates" (typeface and hand- 
written), // "PHALANGOGONIA PARILIS BATES $\hat{\sigma}$ DET: A. B. T. SMITH 2001 PARALECTOTYPE” (yellow type label, handwritten and typeface). One male paralectotype at MGFT labelled "Cerro Zunil, 4-5000 ft. Champion." (typeface), // "B.C.A., Coll., II. (2). Phalangogonia parilis, Bates" (typeface and handwritten), // "PHALANGOGONIA PARILIS BATES $\widehat{\delta}$ DET: A. B. T. SMITH 2001 PARALECTOTYPE" (yellow type label, handwritten and typeface). Bates (1888) stated that there were "numerous specimens" in the type series. All specimens in the type series are males. The location of the remaining male paralectotypes is unknown. One paralectotype was lost in the mail between ZMHB and MXAL in 1993.

Phalangogonia championi Bates, 1888. Lectotype hereby designated: female at BMNH, labelled "Type" (round label, red border, typeface), // "Sp. figured." (typeface), // "Cerro Zunil, 4-5000 ft. Champion." (typeface), // "Phalangogonia championi Bates" (handwritten), // "B.C.A., Coll., II. (2). Phalangogonia championi, Bates" (typeface and handwritten), // "PHALANGOGONIA CHAMPIONI BATES 우 LECTOTYPE A. B. T. SMITH 2001" (red type label, handwritten and typeface), // "Phalangogonia PARILIS BATES o DET: A. B. T. SMITH 2001" (typeface and handwritten). Type locality: Cerro Zunil, Guatemala. Two female paralectotypes at BMNH labelled (with slight variations) "o" (typeface), // "Cerro Zunil, 4-5000 ft. Champion." (typeface), // "Phalangogonia championi Bates" (handwritten), // "B.C.A, Coll., II. (2). Phalangogonia championi Bates" (typeface and hand-written), // "PHALANGOGONIA CHAMPIONI BATES + DET: A. B. T. SMITH 2001 PARALECTOTYPE" (yellow type label, handwritten and typeface), // "Phalangogonia PARILIS BATES + DET: A. B. T. SMITH 2001" (typeface and handwritten). One female paralectotype at ZMHB labelled "Cerro Zunil, 4-5000 ft. Champion." (typeface), // "Co-Type' (round label with yellow border, typeface), // "O”" (typeface), // "B.C.A., Coll., II. (2). Phalangogonia championi Bates" (typeface and handwritten), // "PHALANGOGONIA CHAMPIONI BATES $\bigcirc$ DET: A. B. T. SMITH 2001 PARALECTOTYPE” (yellow type label, handwritten and typeface), // "Phalangogonia PARILIS BATES o DET: A. B. T. SMITH 2001" (typeface and handwritten). Bates (1888) stated that there were seven females in the type series. The location of three female paralectotypes is unknown. Phalangogonia championi was placed in synonymy with $P$. parilis by Ohaus (1904b). This species is known only from the type series collected by Champion in 1880. Champion (1907) collected around Cerro Zunil from 20 August to 9 September 1880 and again from 19 November to 14 December 1880. The type series of P. parilis was likely collected during one of these excursions. Cerro Zunil seems to be an area of high endemism. For example, Jameson (1990) found that Viridimicus nigroaeneus (Bates) (Rutelinae: Rutelini) is also known from only the type series collected by Champion at Cerro Zunil. If the habitat in this area has been destroyed, it is quite possible that these two species ( $P$. parilis and $V$. nigroaeneus) are now extinct.
Diagnosis. This species is distinguished from all other species in Phalangogonia by the following combination of characters: dorsal color tan or black with reddish-brown patches; frons glabrous; eye bulbous, protruding from side of head in dorsal view; pronotum sparsely punctate; pygidial disc granulate; mesometasternal process short, not declivous with respect to venter; male genitalia as in Fig. 2J,K.

Description. Male ( $\mathrm{n}=5$ ): Length $18.2-21.5 \mathrm{~mm}$, width 10.2-11.6 mm. Color dorsally tan. Head: Clypeus reflexed weakly at apex, densely punctate, with moderately large to moderate-sized punctures. Frontoclypeal suture incomplete, obscured medially. Frons sparsely punctate, with moderately large to moderate-sized punctures. Eye bulbous, protruding from side of head in dorsal view, length in lateral view $0.38 \times$ head length in lateral view. Pronotum: Surface sparsely punctate, with moderate-sized punctures, glabrous. Elytron: Surface glabrous. Striae weakly defined. Pygidium: Width $2.0 \times$ length medially. Surface strongly sculptured, granular; moderately setose with long, yellowish-brown setae. Venter: Thorax sparsely setose medially, moderately setose laterally; setae long, yellowish-brown. Mesometasternal process short, apex between procoxae and mesocoxae. Abdominal sternites sparsely setose. Legs: Metatarsomeres 1-3 with weak ventral pad of yellowish-brown setae. Protarsomere 5 with vestigial ventrobasal tooth. Mesotarsomere 5 and metatarsomere 5 with prominent ventrobasal tooth. Tarsal claws with modified claw thickened when compared to other claw, apex bifurcate. Male Genitalia (Fig. 2J,K): Dorsomedially without keel or swelling; apex simple, without tooth. Female $(\mathrm{n}=3)$ : Length $21.8-23.5 \mathrm{~mm}$, width 12.3-13.4 mm. As male except in following respects. Color dorsally black with reddish-brown patch on frons, elytron apex. Head: Clypeal apex rounded, not reflexed. Legs: Tarsal claws with modified claw with ventral tooth, not thickened when compared to other claw, apex not bifurcate.

Distribution (Fig. 4). Known only from the type locality: Cerro Zunil, Guatemala (1200-1500 m). The following locality is based on twelve specimens examined from BMNH, CNCI, HAHC, MGFT, and ZMHB. GUATEMALA: Quezalternango: Cerro Zunil.

\section{Phalangogonia punctata Franz, 1955 (Fig. 4)}

Phalangogonia punctata: Franz, 1955: 206 (original description); Machatschke, 1965: 55 (catalogue listing); Machatschke, 1972: 300 (catalogue listing).

Type Specimens. Phalangogonia punctata Franz (1955). Holotype female at SMFD, labelled "H. Mte. Cristo (2200 m) El Salvador 4.-8.6. Dr. A. Zilch, S. 1951" (typeface and handwritten), // "Phalangogonia spec. $\&$ prope obesa Burm. Machatschke det. 1954." (handwritten and typeface), // "Phalangogonia punctata n. sp. Dr E. Franz det. 1955" (handwritten and typeface), // "Holo-typus" (on upside) "SMF C 8737" (on downside) (red label, handwritten and 
typeface), // PHALANGOGONIA PUNCTATA FRANZ O HOLOTYPE” (red type label, handwritten and typeface). Type locality: Hacienda Monte Cristo, Santa Ana, El Salvador. Franz (1955) indicated that the female holotype is the only specimen in the type series.

Diagnosis. This species is distinguished from all other species in Phalangogonia by the following combination of characters: dorsal color brownish-tan; frons glabrous; eye flush with side of head in dorsal view; pronotum densely punctate; pygidial disc rugose; mesometasternal process robust, weakly declivous with respect to venter.

Description. Female $(n=1)$ : Length $21.7 \mathrm{~mm}$, width 12.3 $\mathrm{mm}$. Color dorsally brownish-tan. Head: Surface densely punctate to rugose, with moderately large to moderate-sized punctures. Clypeal apex rounded, not reflexed. Frontoclypeal suture weakly defined. Eye small, flush with side of head in dorsal view, length in lateral view $0.22 \times$ head length in lateral view. Pronotum: Surface densely punctate, with moderate-sized punctures, glabrous. Elytron: Surface densely punctate, glabrous. Striae weakly defined. Pygidium: Width $2.2 \times$ length medially. Surface strongly sculptured, appearing rugose to granulate; moderately setose with yellowish-brown setae. Venter: Thorax sparsely setose medially, moderately setose laterally; setae long, yellowish-brown. Mesometasternal process slightly angled ventrad away from body, apex adjacent to base of procoxae. Abdominal sternites sparsely setose. Legs: Metatarsomeres 1-3 with weak ventral pad of setae. Tarsomere 5 with ventrobasal tooth. Tarsal claws with modified claw with ventral tooth, not thickened when compared to other claw, apex not bifurcate. Male: Unknown.

Distribution (Fig. 4). Recorded from $2200 \mathrm{~m}$ in elevation in cloud forest habitat in the northern comer of El Salvador (near the borders of Guatemala and Honduras). The following locality is based on one specimen examined from SMFD. EL SALVADOR: Santa Ana: Hacienda Monte Cristo.

Seasonal data. July.

\section{Phalangogonia ratcliffei, sp.n. (Figs 1, 2L,M, 3B, 4)}

Phalangogonia obesa (misapplied): Thomas, 1993: 402 (checklist).

Type specimens. Male holotype deposited at UNSM, forty-eight male paratypes deposited at RACC (6), ABTS (5), BCRC (5), UNSM (5), HAHC (4), LACM (3), TAMU (3), FMNH (2), MLJC (2), MXAL (2), USNM (2), WBWC (2), ZMHB (2), BDGC (1), CNCI (1), DJCC (1), ESUR (1) and UCRC (1). Holotype labelled " $3 \mathrm{~km}$ west, Cinco Cerros, Chiapas, Mexico VI-26-87.” Type locality: $3 \mathrm{~km}$ west of Cinco Cerros, Chiapas, Mexico. Eight paratypes with same label as holotype, three have additional labels "At Light" and "Coll. by W. F. Chamberlain." Two paratypes labelled "MEXICO: Chiapas Cinco Cerros, Hwy 190 at Oaxaca border VI-8-1989 B.C. Ratcliffe." Three paratypes labelled "MEXICO: Chiapas
Cinco Cerros 810m VI-8-1991 B. Ratcliffe, J. Ashe, M. Jameson colls." One paratype labelled "MEXICO, OAXACA 33 KM NE TEPANATEPEC JUNE 181987 E. GIESBERT, COLL." One paratype labelled "MEXICO: Chiapas Cinco Cerros 9.VI. 1990 B. D. Gill 860 m.” Two paratypes labelled "MEXICO, Chiapas Cinco Cerros, Km 30 on Hwy 1901500 m 8.VI. 1989. H. Howden." One paratype labelled "MEXICO, Oaxaca 33 km N Tepanetapec June 18,22. 1987 JE. Wappes." Two paratypes labelled "Mex., $25 \mathrm{mi}$. E. Zanatepec, Chis. 25. VI. 1969, J.Camp-bell \& D. Bright.” Twelve paratypes labelled "MEXICO: CHIAPAS CINCO CERROS 26 JUNE 1988 DB \& AM THOMAS.” One paratype labelled "MEXICO: CHIAPAS CINCO CERROS 3 JULY 1991 D. THOMAS, J. BURNE." One paratype labelled "MEXICO: CHIAPAS CINCO CERROS 8-VI-89 D. THOMAS H. HOWDEN, B. RATCLIFFE.” One paratype labelled "MEXICO: Chiapas: Mpio. Cintalapa de Figueroa, Hwy. 190, 5.8 rd. km. E Rizo de Oro, Hotel Paty, 850 m 18-June-1992, B. D. Streit + R. A. Cunningham Colls., Pine-Oak Forest.” One paratype labelled "MEXICO: Chiapas: Mpio. Cintalapa de Figueroa, Hwy. 190, 5.8 rd. km. E Rizo de Oro, Hotel Paty, 850 m 19-June-1992, B. D. Streit + R. A. Cunningham Colls., Pine-Oak Forest." One paratype labelled "MEXICO: Chiapas: Mpio. Cintalapa de Figueroa, Hwy. 190, 5.8 rd. km. E Rizo de Oro, Hotel Paty, 850 m 20-June-1992, B. D. Streit + R. A. Cunningham Colls., Pine-Oak Forest." Five paratypes labelled "MEXICO: Chiapas Hwy. 190, 6 km E Rizo de Oro, vi-18-21-1990; 890 m." Two paratypes labelled "MEXICO: CHIAPAS Hotel Paty (km 33 on Hwy. 90) 680 m, 6 rd km W Rizo de Oro 18/20-VI-1990 AV Evans BL.” One paratype labelled "MEXICO: Chiapas 850m Hwy 190, Munizipio Cint-atapa, $7 \mathrm{~km}$ E Rizo de Oro Hotel Paty, 21-VI1991 RA Cunningham collector Pine-Oak Forest Lights.” One paratype labelled "MEXICO: Chiapas, Mpio Cintalapa Rizo de Oro pine-oak forest 19-VI-1992 R. A. Cunningham/B. D. Streit, collectors" and "Taken Under MV Lights." One paratype labelled "MEXICO: Chiapas, Mpio Cintalapa, 43 km NW Cintalapa, carretera 190, 5-VII-1995, B. Gómez." One paratype labelled "MEXICO: Mpio Cintalapa de Figueroa, Hwy 190, 5.8 rd km E Rizo de Oro, Hotel Paty, 850 m, 19-VI-1992, B. D. Streit \& R. A. Cunningham collectors, Pine-Oak forest."

Diagnosis. This species is distinguished from all other species in Phalangogonia by the following combination of characters: dorsal color dark tan; frons setose; eye bulbous, protruding from side of head in dorsal view; pronotum moderately to densely punctate; pygidial disc rugose; mesometasternal process short, not declivous with respect to venter; male genitalia as in Fig. 2L,M.

Holotype. Male. Length $26.7 \mathrm{~mm}$, width $14.1 \mathrm{~mm}$. Color dark tan; clypeal, protibial, tarsal margins black. Head: Dorsal surface densely punctate, moderately setose; setae slender, yellowish-brown. Clypeus rectangular; reflexed strongly apically, weakly laterally. Clypeal apex ventrally thickened beyond oral cavity. Frontoclypeal suture complete, bisinuate. Eye large, bulbous, length in lateral view $0.44 \times$ head length in lateral 
view. Antenna 10-segmented, club length subequal to length of basal segments. Labrum broadly triangular, produced perpendicular to clypeus. Apex of mentum with strong, medial tooth reflexed into oral cavity, Pronotum: Surface moderately to densely punctate, moderately setose medioapically; setae fine, yellowish-brown. Lateral margin weakly reflexed. Elytron: Surface glabrous. Striae weakly defined, punctate, with moderate-sized punctures. Pygidium: Width $1.9 \times$ length medially. Surface with roughened appearance (strong microsculpturing), moderately setose, with shorter setae basally; moderately punctate, moderately setose with longer setae apically, setae yellowish-brown. Venter: Thorax densely setose; setae long, yellowish-brown. Mesometasternal process projecting weakly beyond mesocoxae, well separated from procoxae. Abdominal sternites moderately setose. Legs: Protibia with 3 teeth. Mesotibia, metatibia with well developed medial carina. Tarsomeres 1-4 wider than long, cup-shaped. Metatarsomeres 1-3 with ventral pad of yellowish-brown setae. Tarsomere 5 elongate, with ventrobasal tooth. Tarsal claws with modified claw thickened when compared to other claw, apex bifurcate. Male genitalia (Fig. 2L,M): Dorsomedially without keel or swelling; apex weakly angulate, without tooth.

Variation (46 male paratypes). Length 24.2-30.7 mm, width $13.2-16.4 \mathrm{~mm}$. The paratypes do not differ significantly from the holotype. Female unknown.

Etymology. The species name is a noun in the genitive case for "Ratcliffe's Phalangogonia" It is our pleasure to name this species after the eminent scarab beetle taxonomist, Brett Ratcliffe. One of us (ABTS) is particularly grateful for Brett's mentoring, advice and insights, and encouragement to strive for excellence during the course of his $\mathrm{PhD}$ studies at the University of Nebraska.

Habitat. Phalangogonia ratcliffei has been collected at lights in pine-oak forest habitats. The pine-oak forests of Chiapas occur from 750 to $2500 \mathrm{~m}$ in elevation (Thomas, 1993). This species seems to be locally common and the adults are readily collected using lights during the right season.

Distribution (Fig. 4). Recorded from around $800 \mathrm{~m}$ in elevation in the northwestern areas of Sierra Madre de Chiapas at the junction with the eastern slopes of the Sierra de Niltepec, Oaxaca, Mexico. The following localities arc based on forty-nine specimens examined from BCRC, BDGC, CNCI, DBTC, DJCC, ESUR, HAHC, LACM, RACC, TAMU, UNSM and WBWC. MEXICO: Chiapas: Cinco Cerros, Rizo de Oro (6 km E), Zanatepec (40 km E); Oaxaca: Tapanatepec (33 km NE).

Seasonal data. June and July.

\section{Phalangogonia sperata Sharp, 1878 (Figs 2N,O, 3C, 4)}

Phalangogonia sperata: Sharp, 1878: 129, 134 (original description); Bates, 1888: 292 (redescription); Ohaus, 1904b: 265,
268, 338, 340 (redescription); Ohaus, 1905: 167 (illustration); Ohaus, 1918: 176 (catalogue listing); Blackwelder, 1944: 246 (checklist); Machatschke, 1965: 55, 145 (catalogue listing, illustration); Machatschke, 1972: 300 (catalogue listing); Morón, 1995: 200 (comparison with P. lacordairei and P. obesa); Ratcliffe 2002: 26 (checklist); Smith, 2002a: 381 (phylogenetic analysis of Brachysternina).

Phalangogonia stipes: Sharp, 1878: 130, 134 (original description); Bates, 1888: 292 (placed in synonymy with $P$. sperata); Ohaus, 1918: 176 (catalogue listing as synonym of $P$. sperata), Blackwelder, 1944: 246 (checklist as synonym of P. sperata); Machatschke, 1965: 55 (catalogue listing as synonym of P. sperata); Machatschke, 1972: 300 (catalogue listing as synonym of $P$. sperata); Ratcliffe 2002: 26 (checklist as synonym of $P$. sperata).

Phalangogonia debilidens. Ohaus, 1904b: 271, 338, 340 (original description); Ohaus, 1918: 176 (catalogue listing); Blackwelder, 1944: 246 (checklist); Machatschke, 1965: 54 (catalogue listing); Machatschke, 1972: 300 (catalogue listing).

Type specimens. Phalangogonia sperata Sharp (1878). Neotype hereby designated: male at UNSM, labelled "PANAMA: Panama Prov. El Llano-Carti Road., km 8 N9 $16^{\circ}$ ', W78 $57^{\circ}$ V-23-1995, elev. 1,100’ B. Ratcliffe \& M. Jameson” (typeface), // "feeding on Cecropia" (typeface), // "PHALANGOGONIA SPERATA SHARP $O$ NEOTYPE A. B. T. SMITH 2001" (red type label, typeface). Type locality: $\mathrm{km} 8$ on the El Llano-Carti Road, Panama, Panama (approximately $9^{\circ} 16^{\prime} \mathrm{N}$, $\left.78^{\circ} 57^{\prime} \mathrm{W}\right)$. Sharp (1878) indicated that the original description was based on a single specimen from the W. W. Saunders collection. According to Horn et al. (1990) most of the W. W. Saunders collection was deposited in the BMNH and Muséum National d'Histoire Naturelle in Paris. One of us (A.B.T.S.) searched in both these collections and was unable to find the holotype for this species. We can only conclude that the holotype has been lost. The original type was from "Central America." We selected a male neotype from Panama, remaining true to the original type locality. The neotype matches closely the original description for the species by Sharp (1878). One specimen labelled "Typus" was lost in the mail between ZMHB and MXAL in 1993. It is doubtful that this specimen was the true holotype.

Phalangogonia stipes Sharp, 1878. Neotype hereby designated: female at BMNH, labelled "Chontales, Nicaragua.Richardson." (typeface), // "Biol. Cent.-Am. 1905-71." (typeface), // "PHALANGOGONIA STIPES SHARP 9 NEOTYPE A. B. T. SMITH 2001" (red type label, handwritten and typeface), // "Phalangogonia SPERATA SHARP + Det: A. B. T. Smith 2001" (typeface and handwritten). Type locality: Chontales, Nicaragua. As was true for P. sperata, the name P. stipes was named for a single female from the W. W. Saunders collection. The search for the holotype of the latter mirrored that described for the P. sperata holotype, and we concluded that the specimen was lost as well. The holotype of $P$. stipes was from Nicaragua. For the neotype, we selected a specimen from 
Chontales, Nicaragua that matches the original description of P. stipes by Sharp (1878). Bates (1888) first placed the name $P$. stipes in synonymy with $P$. sperata. This has been universally accepted by all others authors working on the group. In fact, Sharp (1878) even doubted the validity of the P. stipes when he described it. He stated that it might prove to be a variety of $P$. sperata. Although the types of these names were lost, the descriptions and locality data leave no doubt to the identity of the species and that the two names are synonyms.

Phalangogonia debilidens Ohaus, 1904, syn.n. Neotype female at INBC, labelled "Amubri, A. C. Amistad., Prov. Limón, COSTA RICA. 70 m 2-31 May 1994, G. Gallardo, L N 385000-578100 \# 2928" (typeface), // "COSTA RICA INBIO CRIOO1871357" (typeface, with bar code), // "PHALANGOGONIA DEBILIDENS OHAUS + NEOTYPE A. B. T. SMITH 2001" (red type label, handwritten and typeface), // "Phalangogonia SPERATA SHARP + Det: A. B. T. Smith 2001" (typeface and handwritten). Type locality: Amubri, Limon, Costa Rica. It is necessary to designate a neotype for $P$. debilidens because the holotype has been lost. The holotype was at ZMHB until it was requested on loan by one of us (MAM) in 1993. According to Hella Wendt (former curator at $\mathrm{ZMHB}$ ) the loan was sent but it, unfortunately, never arrived at its intended address in Mexico. Ohaus (1904b) based his original description on a single female specimen from Costa Rica. We selected a specimen from Limon Province in Costa Rica that matches the original description of $P$. debilidens. Based on the original descriptions, the key differences between $P$. debilidens and $P$. sperata are in the size, form of the mouthparts, coloration, and setae. After examining hundreds of specimens we conclude that these characters can vary within and between populations of $P$. sperata. The original description of $P$. debilidens best matches $P$. sperata individuals from localities in Limon, Costa Rica. Therefore, $P$. debilidens is synonymized with $P$. sperata, and a neotype female is designated from Limon.

Diagnosis. This species is distinguished from all other species in Phalangogonia by the following combination of characters: dorsal color dark tan to tan; frons glabrous; eye bulbous, protruding from side of head in dorsal view; pronotum sparsely punctate; pygidial disc shagreened; mesometasternal process robust, not declivous with respect to venter; male genitalia as in Fig. 2N,O.

Description. Male $(n=312)$ : Length $20.6-32.6 \mathrm{~mm}$, width 11.1-16.9 mm. Color dorsally tan to dark tan. Head: Clypeus rectangular, reflexed strongly at apex, densely punctate, with moderately large to moderate-sized punctures, with sparse setae at apex. Frontoclypeal suture complete, weakly bisinuate. From moderately to densely punctate, with moderately large to moderate-sized punctures, glabrous. Eye bulbous, protruding from side of head in dorsal view, length in lateral view $0.33 \times$ head length in lateral view. Pronotum: Surface sparsely punctate with moderate-sized punctures, glabrous. Elytron:
Surface glabrous. Striae weakly defined. Pygidium: Width 2.4 $\times$ length medially. Surface with noticeable microsculpturing; sparsely setose apically with long, yellowish-brown setae. Venter: Thorax glabrous medially, moderately setose laterally; setae long, yellowish-brown. Mesometasternal process parallel to venter, apex adjacent to procoxae. Abdominal sternites sparsely setose. Legs: Mesotarsomeres 1-3 and metatarsomeres 1-3 with ventral pad of thick, yellowish-brown setae. Protarsomere 5 with vestigial, ventrobasal tooth. Mesotarsomere 5 and metatarsomere 5 with prominent ventrobasal tooth. Tarsal claws with modified claw thickened when compared to other claw, apex bifurcate. Male genitalia (Fig. 2N,O): Dorsomedially with dual keels; apex constricted, without tooth. Female ( $n$ = 102): Length $20.0-29.3 \mathrm{~mm}$, width $11.4-16.0 \mathrm{~mm}$. As male except in following respects. Head: Clypeal apex rounded, not reflexed. Legs: Tarsal claws with modified claw with ventral tooth, not thickened when compared to other claw, apex not bifurcate.

Habitats. Phalangogonia sperata is common in collections, has a fairly widespread distribution, is locally abundant, and is readily collected in cloud forest habitats. Brett Ratcliffe and Mary Liz Jameson have observed clusters of individuals feeding on Cecropia (Cecropiaceae) and Guazuma ulmifolia Lamk. (Sterculiaceae) leaves in Panama. Learning more about the natural history of this species will probably reveal clues about the more elusive species in this genus.

Distribution (Fig. 4). Recorded from 10 to $1520 \mathrm{~m}$ in elevation from north-central Nicaragua to east central Panama. The following localities are based on four hundred and twenty-one specimens (six specimens with no data) examined from ABTS, BCRC, BMNH, CNCI, DBTC, DEIC, DCCC, DJCC, HAHC, INBC, JMMC, MCZC, MGFT, MLJC, MXAL, NHMB, OSAC, RACC, SEMC, SMFD, SMTD, UNSM, USNM, UVGC, ZMHB and ZSMC. HONDURAS: no data. NICARAGUA: Chontales: no data; Jinotega: Las Torres; Matagalpa: Montaña Selva Negra (7.5 km N Matagalpa); Zelaya: Yolaina; no data. COSTA RICA: Alajuela: Colonia Blanca (Parque Nacional Rincon de la Vieja), Estación Las Pailas (Parque Nacional Rincon de la Vieja), Finca San Gabriel, Piedra Negra, Río San Lorencito; Cartago: Tuis; Guanacaste: Cerro El Hacha, Estación Cacao, Estación Las Pailas, Estación Maritza, Estación Mengo, Estación Pitilla, Faldas (SW Volcán Cacao), Finca La Luz (W side Volcán Cacao), Liberia (25 km NE), Los Almendros, Quebrada Grande (11 km E); Heredia: Estación Biológica La Selva, Estación El Ceibo, Estación Magasay, Puerto Viejo; Limón: Amubri, Finca E. Rojas, Reserva Hitoy Cerere, Río Sardinas; Puntarenas: Estación Biológica Monteverde, Estación La Casona, Estación Las Cruces, Finca Cafrosa, Reserva Biológica Monteverde, San Luis, Santa Elena; no data. PANAMA: Chiriqui: Boquete, Café Duran, Chiriqui, Hartmann's Finca, Hato de Volcán, Lino, Santa Clara, Volcán de Chiriqui; Cocle: El Valle; Colón: Colón, Santa Rita Ridge; Panamá: Barro Colorado Island, Cerro Azul, Cerro Campana, Cerro Jefé, El Llano-Carti Road (km 8), Fort 


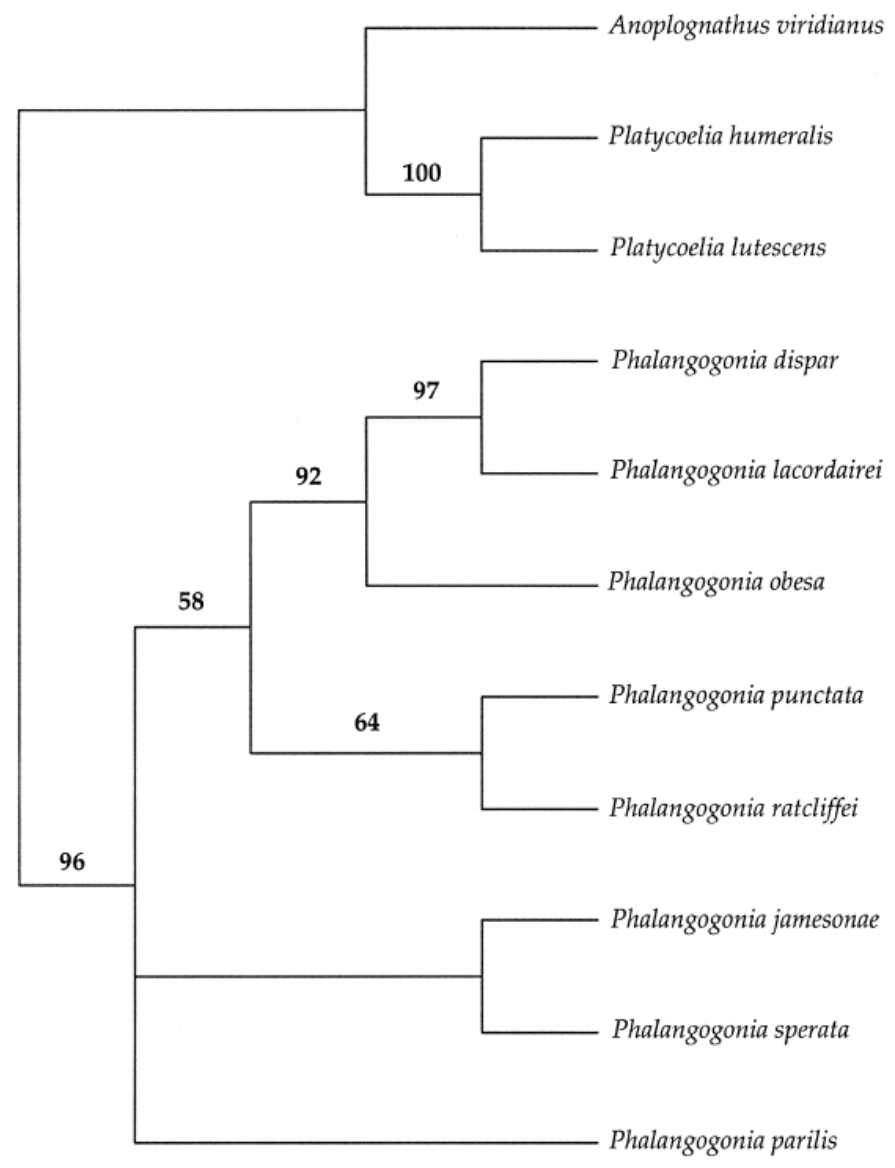

Fig. 5. Strict consensus tree based on the three most parsimonious trees in the phylogenetic analysis of Phalangogonia. Bootstrap support values are indicated above the branches. Only clades with over $50 \%$ bootstrap support are labelled.

Gulick, Gamboa (2 km W), Pipeline Road (km 2.4), Skunk Hollow; no data.

Specimens labelled "Gracias Honduras" were considered to be from Honduras with no further data because it is unclear if they were from Gracias, Lempira, or the department of Gracias a Dios. One specimen labelled "Brazilien" and another labelled "Mexico" were considered unreliable and as having no data.

Seasonal data. Recorded from every month except February.

\section{Phylogenetic analysis of Phalangogonia}

The results of the phylogenetic analyses demonstrate, with high bootstrap support (96\%), that Phalangogonia is a monophyletic clade. The initial branch-and-bound search found nine shortest trees with a length of 70 , consistency index 0.686 , retention index 0.699 and reseated consistency index 0.479 . The succes- sive weighting yielded three most parsimonious trees. Stability was reached with one iteration as tether iterations yielded the same three trees. The three most parsimonious trees after successive weighting are a subset of the nine trees found before reweighting and have a length of $48, \mathrm{CI}$ of 0.760 , RI of 0.791 and rescaled consistency index of 0.601 . The index values are high, indicating that homoplasy is not a major concern and characters in general support monophyletic clades. The consensus tree of the three most parsimonious trees is shown in Fig. 5. Character states that are synapomorphic for Phalangogonia include: pronotum laterally angulate (with impression near angle) (ch. 11); protibia without spur (ch. 21); modified mesoclaw and metaclaw of males thickened, split transversely (chs 23, 26); metatarsomere 5 of male with basal tooth (ch. 25 ); and phallobase greatly reduced, fused to parameres (chs $27,28)$. Other clades with high bootstrap support are the $((P$. punctata $+P$. ratcliffe $i)+(P$. obesa $+(P$. dispar $+P$. lacordairei $)))$ clade and all clades within. The basal lineages have low bootstrap support.

\section{Acknowledgements}

We are very grateful to the individuals and institutions from which specimens were borrowed and for making material available to us for study. We thank Don Thomas (Weslaco, Texas) and Dave Hawks and Doug Yanega (UCRC) for allowing us to distribute paratypes of the two new species to other collections. Julieta Ramos (Universidad Nacional Autónoma de México) is thanked for sharing her unpublished data on the habits and use of P. lacordairei in the mountains of Puebla, Mexico. Dan Schmidt (Schuyler, Nebraska) is gratefully acknowledged for the carbon dust habitus illustration of $P$. ratcliffei. Monty Wood (CNCI) is graciously thanked for giving the senior author the chance to go on three entomological excursions to Costa Rica where Phalangogonia and many other interesting scarabs were observed and collected. Mary Liz Jameson and Brett Ratcliffe (UNSM) are thanked for reviewing this manuscript. Mary Liz Jameson is also acknowledged for penciling some of the line drawings. This project was supported by an NSF/PEET grant (DEB-9712447) to B. C. Ratcliffe and M. L. Jameson.

\section{References}

Bates, H. W. (1888) Insecta. Coleoptera. Rutelidae. Biologia Centrali Americana, 2, 216-296.

Blackwelder, R. E. (1944) Checklist of the coleopterous insects of Mexico, Central America, the West Indies, and South America. Part 2. United States National Museum Bulletin, 185, 189-341.

Browne, D. J. \& Scholtz, C. H. (1995) Phylogeny of the Families of Scarabaeoidea (Coleoptera) based on characters of the hindwing articulation, hindwing base and wing venation. Systematic Entomology, 20, 145-173.

Browne, D. J. \& Scholtz, C. H. (1998) Evolution of the scarab hindwing articulation and wing base: a contribution toward the phylogeny of the Scarabaeidae (Scarabaeoidea: Coleoptera). Systematic Entomology, 23, 307-326. 
Burmeister, H. (1844) Handbuch der Entomologie, vol. 4, part 1. T. C. F. Enslin, Berlin.

Burnham, R. J. E Graham, A. (1999) The history of Neotropical vegetation: new developments and status. Annals of the Missouri Botanical Garden, 86, 546-589.

Carne, P. B. (1956) A revision of Saulostomus Waterhouse and description of a new ruteline genus (Scarabaeidae, Coleoptera). Proceedings of the Linnean Society of New South Wales, 81, 62-70.

Carne, P. B. (1957) A revision of the ruteline genus Anoplognathus Leach (Coleoptera: Scarabaeidae). Australian Journal of Zoology, 5, 88-143.

Carne, P. B. (1958) A review of the Australian Rutelinae (Coleoptera: Scarabaeidae). Australian Journal of Zoology, 6, 162-240.

Champion, G. C. (1907) Itinerary of Mr. G. C. Champion's travels in Central America, 1879-1883. Entomological News, 18, 33-44.

De Ruette, R. (1970) A catalogue of types of Coleoptera in the Canadian National Collection of Insects. Memoirs of the Entomological Society of Canada, 72, 1-134.

Delgado, L., Pérez, A. \& Blackaller, J. (2000) Claves para determinar a los taxones genericos y supragenericos de Scarabaeoidea Latreille, 1802 (Coleoptera) de Mexico. Folia Entomológica Mexicana, 110, 33-87.

Franz, E. (1955) Scarabaeidae Rutelinae (Ins. Col.) aus El Salvador. Senckenbergiana Biologica, 36, 201-207.

Halffter, G. (1978) Un nuevo patrón de dispersión en la Zona de Transición Mexicana: el mesoamericano de montaña. Folio Entomológica Mexicana, 39-40, 219-222.

Harold, E. (1869) Scarabaeidae. Catalogus Coleopterorum Hucusque Descriptorum. Synonymicus et Systematicus, Vol. 4 (ed. by M. Gemminger Eं E. Harold), pp. 979-1346. E. H. Gummi, Munich.

Horn, W., Kahle, I., Friese, G. \& Gaedike, R. (1990) Collectiones Entomologicae. Akademie der Landwirtschaftswissenschaften der Deutschen Demokratischen Republic, Berlin.

International Commission on Zoological Nomenclature (1999) International Code of Zoological Nomenclature. 4th edn. International Commission on Zoological Nomenclature, The Natural History Museum, London.

Iturralde-Vinent, M. A. E̋ MacPhee, R. D. E. (1999) Paleogeography of the Caribbean region: implications for Cenozoic biogeography. Bulletin of the American Museum of Natural History, 238, 1-95.

Jameson. M. L. (1990) Revision, phylogeny and biogeography of the genera. Parabyrsopolis Ohaus and Viridimicus, new genus (Coleoptera: Scarabaeidae: Rutelinae). Coleopterists' Bulletin, 44, 377-422.

Jameson, M. L. E Smith, A. B. T. (2002) Revision of the South American genus. Brachysternus Guérin-Méneville (Coleoptera: Scarabaeidae: Rutelinae: Anoplognathini: Brachysternina). Coleopterists' Bulletin, 56, 321-366.

Lacordaire, J. T. (1856) Histoire Naturelle Des Insectes. Genera Des Coléoptères. Vol. 3. Librairie Encyclopédique de Roret, Paris.

Machatschke, J. W. (1965) Coleoptera Lamellicornia. fam. Scarabaeidae, subfam. Rutelinae, section Rutelinae Orthochilidae. Genera Insectorum, 199, 1-145.

Machatschke, J. W. (1972) Scarabaeoidea: Melolonthidae, Rutelinae. Coleopterum Catalogus Supplementa, 66, 1-361.

Maddison, D. R. \& Maddison, W. P. (2002) MacClade 4.03: Analysis of Phylogeny and Character Evolution, Version 4.03. Sinauer Associates, Sunderland, Massachusetts.

Morón, M. A. (1983) Revision of the subtribe Heterosternina (Coleoptera: Melolonthidae: Rutelinae). Folia Entomologica Mexicana, 55, 31-101.
Morón, M. A. (1991) Estudio biogeográfico-ecologico preliminar del género Plusiotis. Burmeister (Coleoptera: Melolonthidae: Rutelinae). Giornale Italiano Di Entomologia, 5, 309-323.

Morón, M. A. (1994) Las diversidad generica de los coleopteros Melolonthidae en. Mexico. Acta Zoologica Mexicana (Nueva Serie), 61, 7-19.

Morón, M. A. (1995) Las especies mexicanas de Phalangogonia Burmeister (Coleoptera: Melolonthidae, Rutelinae). Giornale Italiano di Entomologia, 7, 195-202.

Morón, M. A. (1997) Capitulo 2, Rutelinae. Atlas de los Escarabajos de Mexico; Coleoptera: Lamellicornia, I. Familia Melolonthidae (ed. by M. A. Morón, B. C. Ratcliffe \& C. Deloya), 9-52. Sociedad Mexicana de Entomología, Mexico.

Morón, M. A. E Blackaller, J. (1997) Melolonthidae y Scarabaeidae. Historia Natural de Los Tuxtlas (ed. by E. González Soriano, R. Dirzo \& R. C. Vogt), pp. 227-243. UNAM-CONABIO. Mexico.

Ohaus, F. (1904a) Revision der Anoplognathiden (Coleoptera lamellicornia). Stettiner Entomologische Zeitung, 65, 57-175.

Ohaus, F. (1904b) Revision der amerikanischen Anoplognathiden (Coleoptera lamellicornia). Stettiner Entomologische Zeitung, 65, 254-341.

Ohaus, F. (1905) Revision der amerikanischen Anoplognathiden (Coleoptera lamellicornia). Stettiner Entomologische Zeitung, 66, 120-167.

Ohaus, F. (1918) Scarabaeidae: Euchirinae, Phaenomerinae, Rutelinae. Coleopterorum Catalogus, 20,1-241. (dated 1915).

Ohaus, F. (1925) Beitrag zur Kenntnis der Ruteliden (Col. lamell.). Deutsche Entomologische Zeitschrifl, 1925, 75-83.

Ratcliffe, B. C. (2002) A checklist of the Scarabaeoidea (Coleoptera) of Panama. Zootaxa, 32, 1-48.

Ratcliffe, B. C. E' Ocampo, F. (2002) A review of the genus Hylamorpha Arrow (Coleoptera: Scarabaeidae: Rutelinae: Anoplognathini: Brachysternina). Coleopterists' Bulletin, 56, 367-378.

Reyes-Castillo, P. \& Halffter, G. (1978) Análisis de la distribución geográfica de la tribu Proculini (Coleoptera: Passalidae). Folia Entomológica Mexicana, 39-40, 222-226.

Sharp, D. (1878) Description of some new species of beetles (Scarabaeidae) from Central America. Journal of the Linnean Society, 13, 129-138.

Smith, A. B. T. (2002) Revision of the southern South American endemic genus. Aulacopalpus Guérin-Méneville with phylogenetic and biogeographic analyses of the subtribe Brachysternina ( $\mathrm{Co}^{-}$ leoptera: Scarabaeidae: Rutelinae: Anoplognathini). Coleopterists' Bulletin, 56, 379-437.

Smith, A. B. T. (2003) A monographic revision of the genus Platycoelia Dejean (Coleoptera: Scarabaeidae: Rutelinae: Anoplognathini). Bulletin of the University of Nebraska State Museum (in press).

Swofford, D. L. (2002) PAUP*. Phylogenetic Analysis Using Parsimony ("and Other Methods), Version 4.0b10. Sinauer Associates, Sunderland, Massachusetts.

Thomas, D. B. (1993) Scarabaeidae (Coleoptera) of the Chiapanecan forests: a faunal survey and chorographic analysis. Coleopterists' Bulletin, 47, 363-408.

Wheeler, Q. D. E Platnick, N. I. (2000) The phylogenetic species concept (sensu Wheeler and Platnick). Species Concepts and Phylogenetic Theory: a Debate (ed. by Q. D. Wheeler \& R. Meier), pp. 55-69. Columbia University Press, New York.

Accepted 3 December 2002 